\title{
Effect of replacing fish meal by yeast hydrolysate on growth and intestinal function of juvenile Jian carp (Cyprinus carpio var. jian)
}

\author{
XIANGYANG YUAN ${ }^{1, *}$, WENBIN LIU*, GUANGZHEN JIANG*, YONGJUN DAI* AND \\ HESHAM EED DESOUKY* \\ School of Life Science and Food Engineering, Huaiyin Institute of Technology, No. 1, Meicheng East Road \\ Huaian - 223 003, China \\ "College of Animal Science and Technology, Nanjing Agricultural University, Nanjing - 210 095, China \\ e-mail: xiangyangyuan007@163.com
}

\begin{abstract}
This experiment was performed to investigate the effects of replacing fish meal in the diet of Cyprinus carpio var. jian (average weight $19.44 \pm 0.06 \mathrm{~g}$ ) by yeast hydrolysate $(\mathrm{YH})$, on growth, intestinal histology and function. Six hundred fish were assigned into five groups and fed with five isonitrogenous and isocaloric diets replacing fishmeal by $0 \%(\mathrm{G} 1), 1 \%$ (G2), 3\% (G3), 5\% (G4) and 7\% (G5) YH. YH supplementation at 3\% level significantly increased average body weight, daily growth index, feed intake, condition factor, specific growth rate, intestinal villi length and digestive and brush-border enzymes activity compared to the control group $(\mathrm{p}<0.05)$. Moreover, YH supplementation significantly increased $(\mathrm{p}<0.05)$ intestinal lipase, $\gamma$ - $G T, \mathrm{Na}^{+} / \mathrm{K}^{+}$-ATPase and $A K P$ expression levels. Intestinal Claudin-7 and Occludin mRNA levels in fish of dietary group G5 were significantly higher $(p<0.05)$ than that in the control group. Replacing fish meal with $3 \%$ YH increased growth performance, intestinal digestion and absorption, as well as improved intestinal villi length without triggering any negative effects on intestinal tight junction structure.
\end{abstract}

Keywords: Enzyme activities, Growth, Intestinal histology, Jian carp, Tight junction structure, Yeast hydrolysate

\section{Introduction}

Rising price and higher demand for fish meal (Ding et al., 2015) resulted in a new thrust to substitute fish meal in aquafeed with less expensive and environment friendly protein sources. A number of studies have focused on plant, animal and single cell protein sources during the last decades. In depth study revealed that the usage of several plant proteins in aquafeeds caused growth inhibition and alterations of intestinal morphology (Baeverfjord, 1996). This was because of imbalance, anti-nutritional factors and poor palatability of the plant proteins (Krogdahl et al., 2003). Animal protein sources were regarded as fish meal substitutes because they have high protein content and no anti-nutritional factors (Mohanta et al., 2012). In recent years, some studies found that high level of fish meal substitution by animal protein caused some negative effects, such as hepatic steatosis, growth inhibition and lower survival rate of fish (Hu et al., 2013). Yeast has been recognised as a potential alternative to fish meal among single cell proteins. Studies on the use of yeast as a substitute in aquafeeds has been performed in different species including freshwater fish (Yuan et al., 2017) and sea fish (Pongpet et al., 2016). Some studies found that yeast played a crucial role in growth and immunity of fish. This was because yeast contain bioactive peptides, vitamins, free nucleotide and mannan oligosaccharide (MOS). Previous studies demonstrated that MOS improved growth (Dimitroglou et al., 2010) and innate immunity (Sang et al., 2009) and modulate the intestinal microbiota of fish (Dimitroglou et al., 2010). However, literature regarding mechanism of replacing fish meal by yeast on fish growth are still limited.

Yeast is used as a protein source and a probiotic in aquaculture, which is attributable to the structural components viz., mannan oligosaccharides (MOS) and $\beta$-glucan in yeast (Gause and Trushenski, 2011). However, these components exist in the cell wall and are not easily absorbed by animals. With the development of fermentation technology, yeast hydrolysate is obtained through enzymatic hydrolysis, which is a mixture containing amino acids, peptides, MOS and $\beta$-glucan. These nutrients are more easily absorbed by animals compared to yeast. Earlier study found that protein hydrolysate has different physiological function, such as antioxidant activity (Penaramos and Xiong, 2001). This may be ascribed to the cooperative effects of a number of peptides, including their ability to scavenge free radicals (Moure et al., 2006). Besides, it was reported that protein hydrolysate also 
could boost immunity in rat (Yamauchi and Suetsuna, 1993), which is mainly due to the fact that the protein hydrolysate containing peptides have a potential effect on the immunological responses (Chen et al., 1995). Furthermore, protein hydrolysates could improve fish growth in different species, such as salmon (Salmo salar) (Berge and Storebakken, 1996), crucian carp (Carassius auratus gibelio) (Gui et al., 2010) and sea bream (Acanthopagrus latus) (Ehsani et al., 2014). However, studies regarding the application of yeast hydrolysate in aquafeed are lacking and therefore the present study investigated the effect of fish meal replacement by yeast hydrolysate in juvenile Jian carp.

Intestine is the site where nutrients are digested and absorbed, which is aided by activity of intestinal enzymes, comprising digestive enzymes and brush-border enzymes (Zhao et al., 2012). Besides digestion and absorption, intestine has barrier function preventing invasion of harmful substances (Huang et al., 2015). Intestinal mucosal barrier is regulated by the paracellular pathway and the transcellular pathway. It was previously demonstrated that the intestinal mucosal enterocytes are linked by tight junction (TJ) proteins (Huang et al., 2015). TJ proteins contain cytosolic proteins zonula occludens- 1 (ZO-1) and transmembrane proteins, such as occludin and claudin, which connect the transmembrane proteins with the cytoskeletal actins (Fanning et al., 1998). Therefore, barrier function of intestinal epithelial cells is regulated by $\mathrm{TJ}$ proteins. Some studies reported that the intestinal barrier function of fish could be affected by many factors, such as additives category (Jiang et al., 2017) and feeding rates (Xu et al., 2016). However, studies regarding effect of dietary yeast supplement on intestine in fish are still quite few.

Jian carp (Cyprinus carpio var. jian) is an important economic freshwater fish that is distributed across the world. FAO reported that the global production of common carp was approximately 4.26 million $\mathrm{t}$ in 2017 (FAO, 2018). In fact, dietary supplementation level of fish meal in carp is about $8 \%$. Therefore, it could approximately save 0.34 million $t$ of fish meal per year. In view of this, the study aimed to assess effects of replacing fish meal by yeast hydrolysate $(\mathrm{YH})$ on growth, intestinal histology and function of Jian carp, which could provide new insights into an alternative to fish meal.

\section{Materials and methods}

\section{Composition of diets}

Ingredients and composition of the diets are given in Table 1. Five experimental diets replacing fish meal by $\mathrm{YH} 0 \%(\mathrm{G} 1), 1 \%(\mathrm{G} 2), 3 \%(\mathrm{G} 3), 5 \%(\mathrm{G} 4)$ and $7 \%$ (G5) were formulated. YH was obtained from Guangdong Hinabiotech Co., Ltd., China. It was derived from enzymatic hydrolysis of yeast using papain and had $56.50 \%$ crude protein, $0.5 \%$ crude lipid, $4.4 \%$ moisture and $9.6 \%$ ash. Carbohydrate source used was wheat flour. Protein was mainly sourced from rapeseed meal, soybean meal, fish meal and cottonseed meal. All ingredients were ground into powder and weighed, then mixed with oil. Finally, water was added to the mixture and the diets were

Table 1. Ingredients and proximate composition of the diets

\begin{tabular}{|c|c|c|c|c|c|}
\hline \multirow{2}{*}{ Ingredients $\%$} & \multicolumn{5}{|c|}{ Diets } \\
\hline & G1 & $\mathrm{G} 2$ & G3 & G4 & G5 \\
\hline Fish meal & 8.00 & 7.52 & 5.92 & 4.31 & 2.75 \\
\hline Yeast hydrolyate & 0.00 & 1.00 & 3.00 & 5.00 & 7.00 \\
\hline Soybean meal & 26.80 & 26.80 & 26.80 & 26.80 & 26.80 \\
\hline Rapeseed meal & 12.00 & 12.00 & 12.00 & 12.00 & 12.00 \\
\hline Cottonseed meal & 13.00 & 13.00 & 13.00 & 13.00 & 13.00 \\
\hline Wheat flour & 26.54 & 26.54 & 26.54 & 26.54 & 26.54 \\
\hline Wheat bran & 8.00 & 7.38 & 6.85 & 6.34 & 5.77 \\
\hline Fish oil & 1.28 & 1.38 & 1.51 & 1.63 & 1.76 \\
\hline Soybean oil & 1.28 & 1.28 & 1.28 & 1.28 & 1.28 \\
\hline $\mathrm{Ca}\left(\mathrm{H}_{2} \mathrm{PO}_{4}\right)_{2}$ & 1.80 & 1.80 & 1.80 & 1.80 & 1.80 \\
\hline Salt & 0.30 & 0.30 & 0.30 & 0.30 & 0.30 \\
\hline Premix $^{a}$ & 1.00 & 1.00 & 1.00 & 1.00 & 1.00 \\
\hline \multicolumn{6}{|c|}{ Proximate composition (drymatter basis) } \\
\hline Crude protein & 34.63 & 34.52 & 34.37 & 34.67 & 34.78 \\
\hline Crude lipid & 5.21 & 5.31 & 5.28 & 5.39 & 5.37 \\
\hline Moisture & 9.06 & 8.60 & 8.73 & 9.19 & 8.99 \\
\hline Ash & 7.72 & 7.43 & 7.26 & 7.36 & 7.44 \\
\hline Energy $\left(\mathrm{MJ} \mathrm{kg}^{-1}\right)$ & 18.14 & 18.15 & 18.08 & 18.23 & 17.83 \\
\hline
\end{tabular}


made using a pellet mill (Guangyuan Engineering Co., Ltd., China) and stored at $-20^{\circ} \mathrm{C}$, after drying.

\section{Experimental fish and design}

Experimental fish were bought from the Freshwater Fisheries Research Institute of Jiangsu Province, China. Six hundred healthy fish (average weight 19.44 $\pm 0.06 \mathrm{~g}$ ) were distributed into five groups, each group in four cages $(2.0 \times 1.0 \times 1.7 \mathrm{~m})$ anchored in a pond. In order to ensure water quality, quarter of water in the pond was exchanged biweekly. Fish were acclimated for 14 days and fed with a commercial diet. After acclimation, the experimental fish groups were fed with one of five diets with four replicates for each diet. All experimental fish were fed three times daily for 10 weeks. During the experimental period, water temperature ranged from $23-29^{\circ} \mathrm{C}, \mathrm{pH}$ ranged between 6.6 - 7.4 and dissolved oxygen level was recorded at 6.5 $\mathrm{mg} \mathrm{1^{-1 }}$.

Prior to sampling, experimental fish were starved for $24 \mathrm{~h}$. Three fish from each cage were anesthetised using MS-222 (Sigma-Aldrich, USA) and body weight and length of these sampled fish were measured. Hepatopancreas and viscera were removed and weighed carefully. The proximal intestine of fish was collected for histotlogical, enzymes activity and real-time PCR analysis. Two fishes were selected from each cage for whole body proximate composition analysis.

\section{Proximate composition analysis}

Proximate composition of whole body and diets were estimated following standard protocols (AOAC, 1995): Crude protein was analysed by Kjeldahl method; crude lipid by ether extraction and gross energy level by Bomb Calorimeter (Parr 1281, USA). Moisture content was analysed after drying in oven and ash content was analysed after combustion at $550^{\circ} \mathrm{C}$ for $4 \mathrm{~h}$.

Intestinal enzymes activity assay

Samples from proximal intestine was weighed and then homogenised with 9 volumes of ice cold normal saline. The homogenate was centrifuged at $4000 \mathrm{~g}$ for $10 \mathrm{~min}$. The supernatant was stored in refrigerator $\left(-20^{\circ} \mathrm{C}\right)$ for intestinal enzymes activity assay. Lipase level was quantified by the method of Gjellesvik et al. (1992). Protease activity was analysed using Folin phenol reagent (Cupp-Enyard, 2008); creatine kinase (CK) activity was determined following the procedures stated by Weng et al. (2002); amylase activity was determined based on the procedures detailed by Furne et al. (2005); AKP and $\gamma$-GT activities were quantified based on the method detailed by Engstad et al. (1992) and Rosalki et al. (1970) and $\mathrm{Na}^{+} / \mathrm{K}^{+}$-ATPase was measured according to the procedures by McCormick (1993).

\section{Intestinal histology}

Samples from intestine were initially fixed in $4 \%$ formalin overnight and dehydrated using different graded ethanol concentrations. Then they were cleared in xylene and embedded in paraffin wax, tissue sections were cut in a microtome (Leica RM2235, Germany) at $6 \mu \mathrm{m}$ thickness. Finally, the sections were stained with hematoxylin and eosin (H\&E) and stained sections were photographed using a compound microscope (Nikon, Japan).

\section{$R N A$ extraction and expression}

RNA was isolated from intestine (about $50 \mathrm{mg}$ ) of fish using Trizol reagent (Takara, Japan). The quality and concentration of isolated RNA was analysed using ultramicro spectrophotometer (Thermo scientific, USA) and purity of RNA was determined based on OD260/OD280 ratio. Then the first-strand cDNA was synthesised using reverse transcription kit (Takara, Japan).

The primers for real-time PCR were designed by Premier program version 5.0 (Premier, Canada) (Table 2). All primers used in this experiment were sourced from Generay (Shanghai) Biotech Co., Ltd., China. The polymerase chain reaction (PCR) conditions used were: $94^{\circ} \mathrm{C}$ for $5 \mathrm{~s}, 60^{\circ} \mathrm{C}$ for $30 \mathrm{~s}$, followed by a melt curve analysis of $15 \mathrm{~s}$ from 95 to $60^{\circ} \mathrm{C}, 1 \mathrm{~min}$ for $60^{\circ} \mathrm{C}$ and then up to $95^{\circ} \mathrm{C}$ for $15 \mathrm{~s}$. Finally, the gene relative expression level was calculated according to the $2^{-\Delta \Delta \text { ct }}$ method:

\section{Calculation of growth parameters}

Feed intake $\left(\mathrm{FI}, \mathrm{g} \mathrm{fish}^{-1}\right)=$ Feed intake in each cage $(\mathrm{g}) /$ Number of fishes in the cage

Average body weight $(\mathrm{ABW})=[($ Final body weight $)+($ Initial body weight)]/2

Daily growth index $($ DGI, \% $)=\left[(\text { Final body weight })^{1 / 3}-\right.$ (Initial body weight $\left.)^{1 / 3}\right] \times 100 /$ days

Specific growth rate $\left(\mathrm{SGR}, \%\right.$ day $\left.^{-1}\right)=[\ln ($ Final body weight $)-\ln$ (Initial body weight) $] \times 100 /$ days

Condition factor $(\mathrm{CF} \%)=$ Body weight $(\mathrm{g}) \times 100 /$ Body length $(\mathrm{cm})^{3}$

Hepatosomatic index (HSI, \%) = Hepatopancreas weight $(\mathrm{g}) \times 100 /$ Body weight $(\mathrm{g})$

Viscerasomatic index $($ VSI, \%) $=$ Viscera weight $(\mathrm{g}) \times 100 /$ Body weight $(\mathrm{g})$

\section{Statistical analysis}

The experimental data was analysed by SPSS 19.0 (SPSS Inc., Chicago, American) using one-way ANOVA after testing the normality and homogeneity of variances of data. The significant difference level is set at $\mathrm{p}<0.05$. The data are expressed as means \pm standard error of the mean (SEM). 
Table 2. Nucleotide sequences of the primers used for real-time PCR

\begin{tabular}{|c|c|c|c|c|}
\hline Function & Gene & Primer type & Sequence & Genbank Accession no \\
\hline \multirow[t]{2}{*}{ Housekeeping gene } & \multirow[t]{2}{*}{$40 S$} & Sense & GGAAGTGGCAAGGAGAAG & \multirow[t]{2}{*}{ AB012087 } \\
\hline & & Anti-sense & GGAGAGGTGGACAGACAT & \\
\hline \multirow[t]{8}{*}{ Tight junction protein genes } & \multirow[t]{2}{*}{ Claudin-3c } & Sense & TCACGGCACAAGTCATCTGG & \multirow[t]{2}{*}{ JQ767157.1 } \\
\hline & & Anti-sense & CGGTGGACAGTAACCGGGTTG & \\
\hline & \multirow[t]{2}{*}{ Claudin-7 } & Sense & CCCCAATGGAAGATGTCTGC & \multirow[t]{2}{*}{ JQ767155.1 } \\
\hline & & Anti-sense & AAACGTACTCCTTGCTGCTG & \\
\hline & \multirow[t]{2}{*}{ Occludin } & Sense & ATCGGTTCAGTACAATCAGG & \multirow[t]{2}{*}{ KF975606 } \\
\hline & & Anti-sense & GACAATGAAGCCCATAACAA & \\
\hline & \multirow[t]{2}{*}{$Z O-1$} & Sense & GCGAAATGACACGGGCTAT & \multirow[t]{2}{*}{ KY290394.1 } \\
\hline & & Anti-sense & CTCTGTTGTGGTTGAGTGTAGGC & \\
\hline \multirow[t]{4}{*}{ Digestive enzyme genes } & \multirow[t]{2}{*}{ Lipase } & Sense & GCGAAATGACACGGGCTAT & \multirow[t]{2}{*}{ JF411610.1 } \\
\hline & & Anti-sense & CTCTGTTGTGGTTGAGTGTAGGC & \\
\hline & \multirow[t]{2}{*}{ Amylase } & Sense & GGCTGGATTCAGAGTAGA & \multirow[t]{2}{*}{ JN032758 } \\
\hline & & Anti-sense & CAAGTGGTATTGAGGGTC & \\
\hline \multirow[t]{6}{*}{ Absorptive enzyme genes } & \multirow[t]{2}{*}{$A K P$} & Sense & ACCAATGCTCAGGTCCCA & \multirow[t]{2}{*}{ JF411614 } \\
\hline & & Anti-sense & CGCTCACTCCAACCGTAC & \\
\hline & \multirow[t]{2}{*}{$N a^{+} / K^{+}-A T P$} & Sense & TGCCAGAACTTCTCCACA & \multirow[t]{2}{*}{ JN032759 } \\
\hline & & Anti-sense & AGCGATACCCATAGCCAC & \\
\hline & \multirow[t]{2}{*}{$\gamma-G T$} & Sense & GTGGCTCAGCGGTAGATG & \multirow[t]{2}{*}{ JF411613 } \\
\hline & & Anti-sense & CCACTTTGTTCCCGTATTG & \\
\hline
\end{tabular}

\section{Results}

Effects of experimental diets on the growth of Jian carp

As can be seen from Table 3, ABW, ADI, SGR and FI of fish significantly increased $(\mathrm{p}<0.05)$ with $\mathrm{YH}$ supplementation level from $0 \%$ to $3 \%$, but decreased with further increase in $\mathrm{YH}$ levels. Besides, $3 \% \mathrm{YH}$ significantly increased CF of fish compared to the control diet $(\mathrm{p}<0.05)$. No significant difference ( $p>0.05)$ was observed for HSI and VSI among all groups.

Effects of experimental diets on the whole body composition of Jian carp

The whole body composition of juvenile Jian carp is given in Table 4. No significant differences $(\mathrm{p}>0.05)$ were observed for ash, moisture and crude protein among all groups. Ether extract and gross energy of fish in G3 were significantly higher than that in the control group $(\mathrm{p}<0.05)$
Effects of experimental diets on intestinal enzymes activity of Jian carp

YH supplementation levels affected the intestinal enzymes activity of juvenile Jian carp (Table 5). Protease, lipase, amylase, $\mathrm{CK}$ and activities increased with $\mathrm{YH}$ levels from 0 to $3 \%(\mathrm{p}<0.05)$, with the maximum value observed in fish fed 3\% YH; 1 and 3\% YH significantly increased the $\mathrm{Na}^{+} / \mathrm{K}^{+}$-ATPase and AKP activities compared to the control diet $(\mathrm{p}<0.05)$.

mRNA levels of digestive and brush-border enzymes

As can be seen from Fig. 1, YH supplement significantly increased $(\mathrm{p}<0.05)$ intestinal lipase, $A K P$, $\mathrm{Na}^{+} / \mathrm{K}^{+}$-ATPase and $\gamma$-GT expression levels of juvenile Jian carp of treated groups compared to the control group. Intestinal Amylase mRNA level of fish fed 3 and 5\% YH was significantly higher than that in fish fed the control $\operatorname{diet}(\mathrm{p}<0.05)$.

Table 3. Growth and body parameters of juvenile Jian carp fed different experimental diets

\begin{tabular}{llllll}
\hline Items & \multicolumn{5}{c}{ Diets } \\
\cline { 2 - 5 } & G1 & G2 & G3 & G4 & G5 \\
\hline ABW (g) & $82.26 \pm 2.42^{\mathrm{a}}$ & $90.35 \pm 4.30^{\mathrm{ab}}$ & $99.01 \pm 4.24^{\mathrm{b}}$ & $89.94 \pm 6.17^{\mathrm{ab}}$ & $87.92 \pm 5.45^{\mathrm{ab}}$ \\
DGI (\%) & $3.67 \pm 0.09^{\mathrm{a}}$ & $3.93 \pm 0.15^{\mathrm{ab}}$ & $4.20 \pm 0.12^{\mathrm{b}}$ & $3.92 \pm 0.20^{\mathrm{ab}}$ & $3.84 \pm 0.19^{\mathrm{ab}}$ \\
SGR (\%) & $2.88 \pm 0.06^{\mathrm{a}}$ & $3.02 \pm 0.09^{\mathrm{ab}}$ & $3.17 \pm 0.06^{\mathrm{b}}$ & $3.01 \pm 0.11^{\mathrm{ab}}$ & $2.96 \pm 0.11^{\mathrm{ab}}$ \\
FI (g fish & $115.67 \pm 4.04^{\mathrm{a}}$ & $125.65 \pm 6.91^{\mathrm{ab}}$ & $143.39 \pm 6.94^{\mathrm{b}}$ & $129.20 \pm 12.01^{\mathrm{ab}}$ & $126.31 \pm 7.63^{\mathrm{ab}}$ \\
CF (\%) & $1.98 \pm 0.01^{\mathrm{a}}$ & $2.09 \pm 0.07^{\mathrm{ab}}$ & $2.17 \pm 0.05^{\mathrm{b}}$ & $2.10 \pm 0.03^{\mathrm{ab}}$ & $1.98 \pm 0.04^{\mathrm{a}}$ \\
HSI (\%) & $7.78 \pm 0.08$ & $7.77 \pm 0.03$ & $7.94 \pm 0.08$ & $7.88 \pm 0.16$ & $7.69 \pm 0.10$ \\
VSI (\%) & $1.19 \pm 0.03$ & $1.23 \pm 0.03$ & $1.27 \pm 0.01$ & $1.21 \pm 0.04$ & $1.18 \pm 0.04$ \\
\hline
\end{tabular}

Values are means \pm S.E.M of four replications. Means in the same line with different superscripts are significantly different ( $<0.05$ ).

ABW-average body weight; DGI-daily growth index; SGR-specific growth rate; FI-feed intake; CF-condition factor; HSI-hepatosomatic index; VSI-viscerasomatic index 
Table 4. Whole body composition (\% wet weight basis) of juvenile Jian carp fed experimental diets

\begin{tabular}{llllll}
\hline \multirow{2}{*}{ Parameters } & \multicolumn{5}{c}{ Diets } \\
\cline { 2 - 6 } & G1 & G2 & G3 & G4 & G5 \\
\hline Ash (\%) & $2.91 \pm 0.20$ & $2.98 \pm 0.10$ & $2.83 \pm 0.18$ & $2.76 \pm 0.13$ & $2.48 \pm 0.27$ \\
Moisture (\%) & $76.71 \pm 0.36$ & $76.36 \pm 0.24$ & $76.27 \pm 0.43$ & $75.97 \pm 0.34$ & $76.36 \pm 0.80$ \\
Crude protein (\%) & $15.82 \pm 0.23$ & $15.68 \pm 0.18$ & $15.43 \pm 0.20$ & $15.63 \pm 0.16$ & $15.02 \pm 0.47$ \\
Ether extract (\%) & $3.94 \pm 0.14^{\mathrm{a}}$ & $4.09 \pm 0.14^{\mathrm{a}}$ & $4.72 \pm 0.29^{\mathrm{b}}$ & $4.25 \pm 0.08^{\mathrm{ab}}$ & $4.19 \pm 0.24^{\mathrm{ab}}$ \\
Gross energy (MJ kg-1) & $21.91 \pm 0.36^{\mathrm{a}}$ & $22.35 \pm 0.24^{\mathrm{ab}}$ & $23.55 \pm 0.28^{\mathrm{c}}$ & $23.17 \pm 0.25^{\mathrm{bc}}$ & $22.15 \pm 0.20^{\mathrm{a}}$ \\
\hline
\end{tabular}

Values are means \pm S.E.M of four replications. Means in the same line with different superscripts are significantly different $(\mathrm{p}<0.05)$.

Table 5. Effects of FM replacement by YH on proximal intestinal digestive and brush-border membrane enzymes activity of juvenile Jian carp fed experimental diets

\begin{tabular}{llllll}
\hline \multirow{2}{*}{ Items } & \multicolumn{5}{c}{ Diets } \\
\cline { 2 - 5 } & $\mathrm{G} 1$ & $\mathrm{G} 2$ & $\mathrm{G} 3$ & $\mathrm{G} 4$ & $\mathrm{G} 5$ \\
\hline Protease $\left(\mathrm{U} \mathrm{mg}^{-1}\right)$ & $67.86 \pm 1.79^{\mathrm{a}}$ & $72.98 \pm 4.37^{\mathrm{ab}}$ & $82.17 \pm 3.49^{\mathrm{b}}$ & $67.36 \pm 3.11^{\mathrm{a}}$ & $66.86 \pm 1.94^{\mathrm{a}}$ \\
Lipase $\left(\mathrm{U} \mathrm{mg}^{-1}\right)$ & $23.21 \pm 0.53^{\mathrm{a}}$ & $27.41 \pm 2.88^{\mathrm{ab}}$ & $29.08 \pm 0.87^{\mathrm{b}}$ & $26.670 .94^{\mathrm{ab}}$ & $24.82 \pm 0.81^{\mathrm{ab}}$ \\
Amylase $\left(\mathrm{U} \mathrm{mg}^{-1}\right)$ & $0.18 \pm 0.00^{\mathrm{a}}$ & $0.19 \pm 0.01^{\mathrm{a}}$ & $0.21 \pm 0.00^{\mathrm{b}}$ & $0.19 \pm 0.00^{\mathrm{a}}$ & $0.17 \pm 0.00^{\mathrm{a}}$ \\
$\mathrm{CK}\left(\mathrm{U} \mathrm{g}^{-1}\right)$ & $2.54 \pm 0.03^{\mathrm{a}}$ & $2.95 \pm 0.14^{\mathrm{ab}}$ & $3.09 \pm 0.17^{\mathrm{b}}$ & $2.75 \pm 0.05^{\mathrm{ab}}$ & $2.49 \pm 0.12^{\mathrm{a}}$ \\
$\mathrm{Na}^{+} / \mathrm{K}^{+}-\mathrm{ATPase}^{\mathrm{a}}\left(\mathrm{U} \mathrm{g}^{-1}\right)$ & $0.63 \pm 0.01^{\mathrm{a}}$ & $0.77 \pm 0.01^{\mathrm{b}}$ & $0.78 \pm 0.03^{\mathrm{b}}$ & $0.70 \pm 0.02^{\mathrm{a}}$ & $0.66 \pm 0.02^{\mathrm{a}}$ \\
$\mathrm{AKP}\left(\mathrm{U} \mathrm{g}^{-1}\right)$ & $0.78 \pm 0.03^{\mathrm{a}}$ & $0.98 \pm 0.07^{\mathrm{b}}$ & $0.98 \pm 0.03^{\mathrm{b}}$ & $0.72 \pm 0.03^{\mathrm{a}}$ & $0.64 \pm 0.05^{\mathrm{a}}$ \\
$\gamma$-GT $\left(\mathrm{U} \mathrm{g}^{-1}\right)$ & $69.53 \pm 1.47^{\mathrm{a}}$ & $80.92 \pm 2.39^{\mathrm{ab}}$ & $86.65 \pm 4.88^{\mathrm{b}}$ & $72.5 \pm 1.33^{\mathrm{a}}$ & $69.77 \pm 3.13^{\mathrm{a}}$ \\
\hline
\end{tabular}

Values are means \pm S.E.M of four replications. Means in the same line with different superscripts are significantly different $(\mathrm{p}<0.05)$.

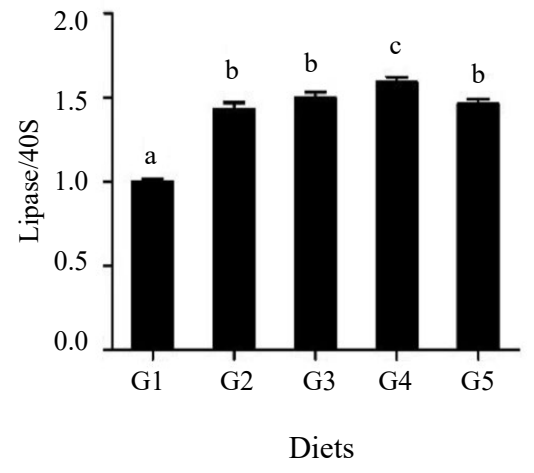

(a)

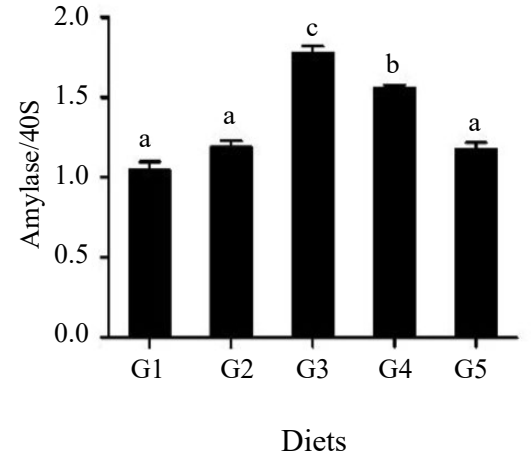

(b)

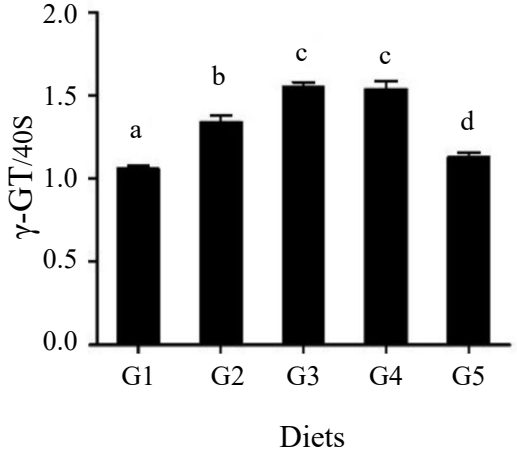

(c)

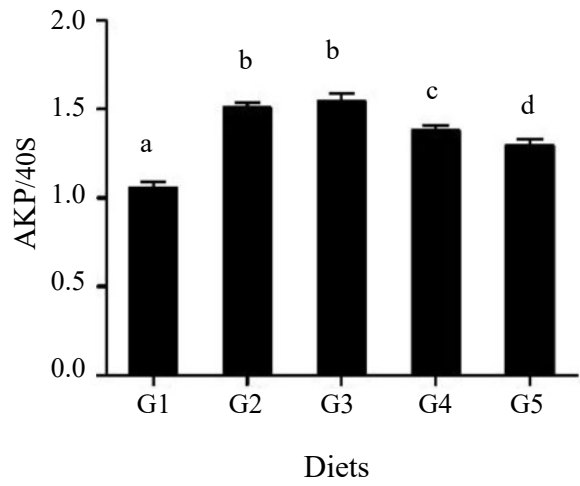

(d)

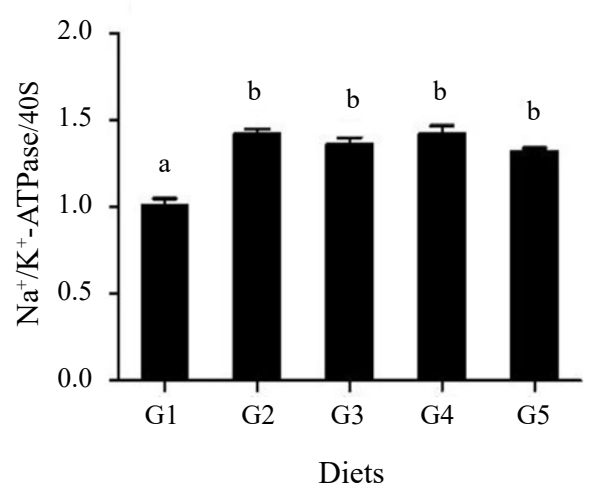

(e)

Fig. 1. Expression levels of Lipase (A), Amylase (B), AKP (C), $N a^{+} / K^{+}$-ATPase (D) and $\gamma-G T$ (E) in proximal intestine of juvenile Jian carp. AKP : alkaline phosphatase; $\gamma$-GT $: \gamma$-glutamyltransferase; Values are means \pm S.E.M of four replicates. Bars with different letters are significantly different $(\mathrm{p}<0.05)$ 
Effects of experimental diets on the intestinal histology of Jian carp

As evident from Figs. 2 and 3 intestinal villi length increased with $\mathrm{YH}$ level increase from 0 to $3 \%$, with the highest values in the fish fed 3\% YH, which decreased with further increase in supplementation level.

\section{Expression levels of tight junction proteins}

No significant difference was observed for Claudin-3c expression levels in intestine among all groups (Fig. 4). Claudin-7 mRNA level in fish fed 3 and $7 \%$ YH were significantly higher than that in fish fed the control diet $(\mathrm{p}<0.05)$. Occludin mRNA level in fish of G2 and G5 diet groups significantly increased compared to the control group $(\mathrm{p}<0.05)$. ZO-1 mRNA level in fish from G4 diet group was significantly higher than that in the control group $(\mathrm{p}<0.05)$.

\section{Discussion}

In this study, $3 \% \mathrm{YH}$ significantly increased ABW, ADI and SGR of juvenile Jian carp. This result might be ascribed to growth promoting function of MOS in yeast (Dimitroglou et al., 2010). Similar findings were observed in different species, such as sea bream (Dimitroglou et al., 2010), sunshine bass (Gause and Trushenski, 2011) and Nile tilapia (Oreochromis niloticus) (Desaleb et al., 2008). Unlike the above cases, He et al. (2011) found that the growth of tilapia was not affected by additional levels of yeast fermentation product. This discrepancy between the findings is reasonable because of the difference in yeast species, fish species and fish life stages (Tovar et al., 2002). However, growth performance of juvenile Jian carp decreased with further increase in YH levels in this experiment. Imbalance of essential amino acids may account for this result (Yuan et al., 2017). The result was in line with the report of Roa et al. (2010) who found that 70 and $100 \%$ of dietary fishmeal replacement with yeast resulted in poor growth of pacu (Piaractus mesopotamicus).

In the present study, 3\% YH increased $\mathrm{CF}$ of fish compared to the control diet. It was not surprising since CF was positively correlated with specific growth rate as reported by Harpaz et al. (2005). The result was found in line with the growth of fish in this study. On the contrary, Kafilzadeh et al. (2013) reported that Saccharomyces cerevisiae supplementation levels had no effect on $\mathrm{CF}$ of oscar fish (Astronotus ocellatus). In addition, in the present study both HSI and VSI showed no significant

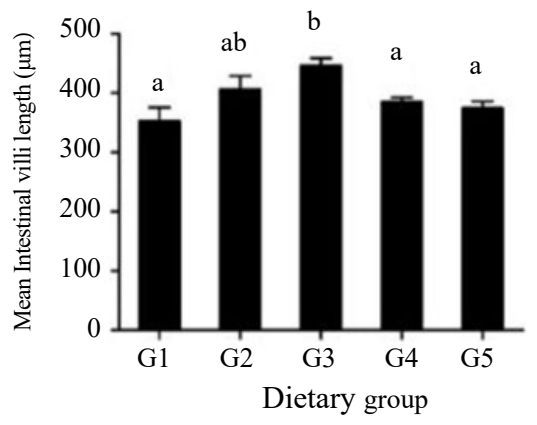

Fig. 3 Intesnal villi length corresponding to different dietary groups of juvenile Jian carp

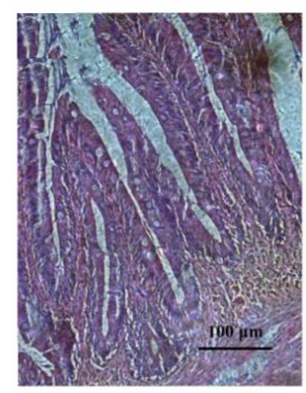

(a)

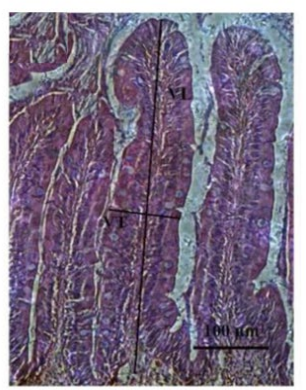

(b)

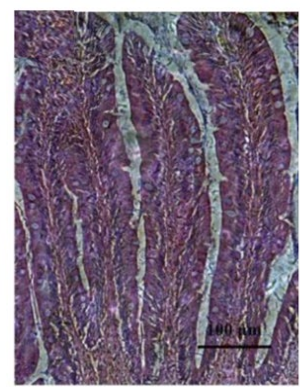

(c)

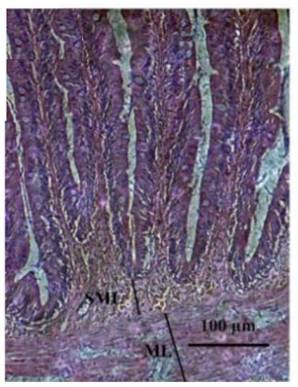

(d)

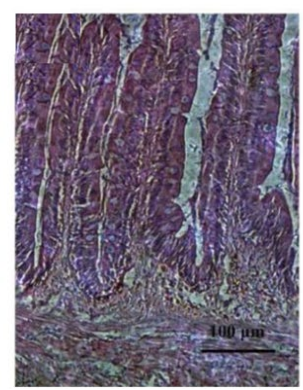

(e)

Fig. 2. Longitudinal sections of the intestine of juvenile Jian carp fed with diets. (a) G1, (b) G2, (c) G3, (d) G4 and (e) G5 


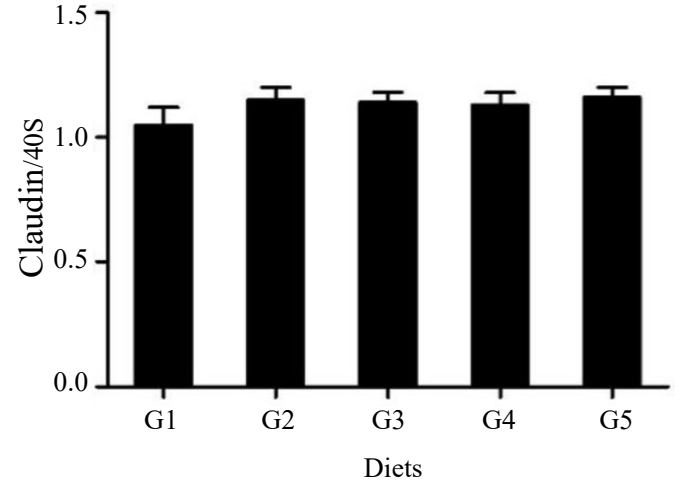

(a)

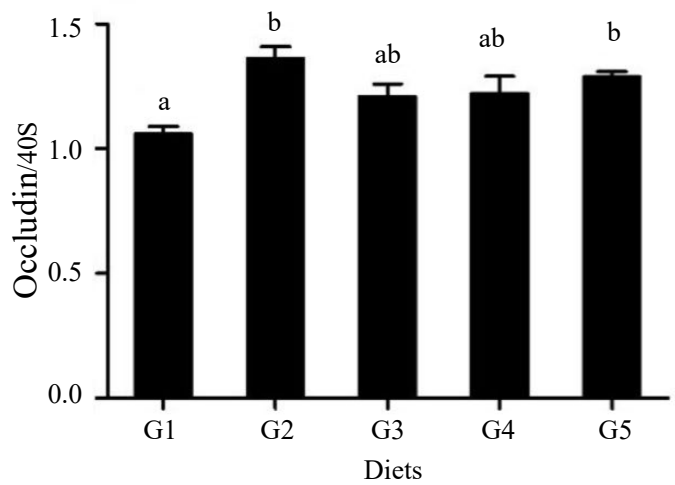

(c)

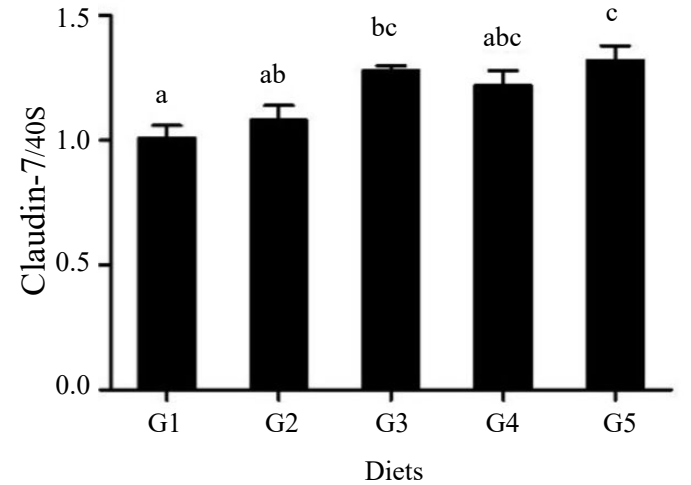

(b)

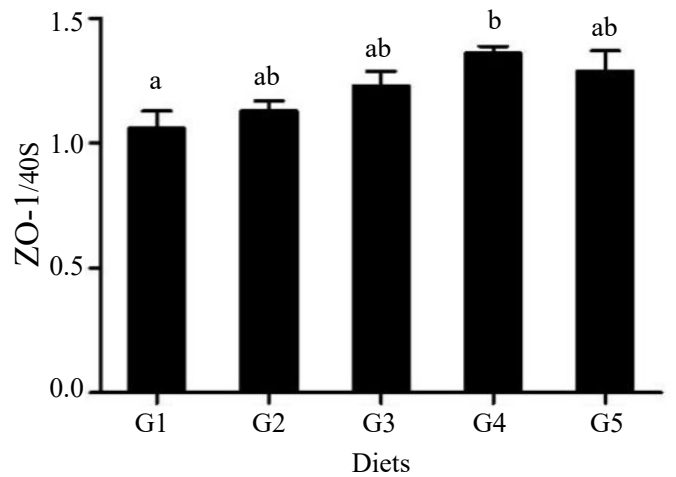

(d)

Fig. 4. Expression levels of (a) Claudin-3c, (b) Claudin-7, (c) Occludin and (d) ZO-1 in proximal intestine of different dietery groups of juvenile Jian carp. Values are means \pm S.E.M of four replicates. Bars with different letters are significantly different $(p<0.05)$

difference among all groups. Similarly, HSI and VSI of seabass juveniles were not affected by brewer's yeast inclusion levels (Oliva-Teles and Goncalves, 2001). Also, Kafilzadeh et al. (2013) found S. cerevisiae supplementation levels had no effects on HSI and VSI of oscar fish.

In this study, we found that $3 \% \mathrm{YH}$ increased ether extract and gross energy of fish compared to the control diet. This could be attributed to the fact that crude protein and gross energy of fish are influenced by dietary energy intake (Lanari et al., 1999). Generally, energy intake of fish increased with increasing food intake. Excessive energy would trigger crude lipid accumulation of fish. This explanation was supported by data of FI in this study. Similar findings were obtained by Lara-Flores et al. (2003) who reported dietary supplementation of yeast increased ether extract of Nile tilapia. However, no difference in crude lipid has been reported in earlier studies (Carter and Hauler, 2000). Differences in results as compared to published reports could be attributed to differences in species of fish and yeast (Tovar et al., 2002).

Nutrient digestion and absorption in intestine mainly depends on intestinal digestive and brush-border membrane enzymes. Therefore, intestinal enzymes activity was generally used as an indicator of fish digestion and absorption (Wu et al., 2013). In this study, protease, lipase and amylase contents of fish fed 3\% YH significantly increased compared to the control group, suggesting that replacing fish meal with $\mathrm{YH}$ at appropriate levels could increase intestinal digestive ability of fish. The increased digestive enzyme activity was helpful for absorption of nutrients, thereby contributing to increasing that growth performance of fish. Previous study reported that yeast could synthesise and secrete different polyamines, which participates in the differentiation and maturation of intestinal cells in animals (Buts et al., 1993). A similar finding has been reported in seabass (Tovar et al., 2002). Furthermore, the brush-border enzymes including CK, $\mathrm{Na}^{+} / \mathrm{K}^{+}$-ATPase, AKP and $\gamma-\mathrm{GT}$, are involved in nutrient absorption of fish (Zhao et al., 2012). CK plays a crucial role in energy metabolism (Decking et al., 2001). $\gamma$-GT and $\mathrm{Na}^{+} / \mathrm{K}^{+}$-ATPase are involved in the active transport and absorption of amino acids (Ogawa et al., 1998). AKP activities reflects absorptive ability of the intestine (Cuvier-Peres and Kestemont, 2001). In this study, CK, $\gamma$-GT, $\mathrm{Na}^{+} / \mathrm{K}^{+}$-ATPase and AKP activities increased as $\mathrm{YH}$ levels increased from 0 to $3 \%$, with the maximum value 
observed in fish fed 3\% YH. However, these enzymes activity decreased with further increase in $\mathrm{YH}$ levels. The present results indicated that 3\% YH enhanced the absorption of nutrients and smilar result was reported in seabass by Tovar et al. (2002). Intestinal digestion and absorption of fish positively have a strong relationship with intestinal morphology. Microvilli length in intestine is positively related with the absorptive surface area of intestine (Yan and Zhou, 2006). Previous literature reported that different nutritional factors had effects on maturation and differentiation of intestinal cells (Dufour et al., 1988). In this current study, 3\% YH significantly increased intestinal villi length of juvenile Jian carp. This result suggested that replacing fish meal with YH at moderate levels increased intestinal absorptive capacity of fish. Previous study found that microvilli length was positively related to the intestinal absorptive surface area (Yan and Zhou, 2006). Therefore, microvilli length could reflect absorption ability of fish instestine. Similarly, a study in Nile tilapia demonstrated that baker's yeast improved intestinal microvilli (Ran et al., 2015).

Tight junction (TJ) proteins structure plays a crucial role in maintaining the physical barrier function in animals (Fanning et al., 1998). Occludin is an integral membrane protein, which participate in maintaining the integrity and barrier function of the TJ structure (Hossain and Hirata, 2008). Claudins are the family of transmembrane proteins, which maintain stabilisation of intercellular TJ structure and determine selective paracellular permeability of epithelial surfaces (Groschwitz and Hogan, 2009). ZO-1 is one of linker proteins, which link cytoskeleton proteins to plasma membrane (Hossain and Hirata, 2008). In this current study, YH supplement levels could not decrease the TJ proteins mRNA level, indicating that dietary YH did not disrupt intestinal barrier function of fish. This was because the decrease in TJ proteins mRNA levels were observed in injured intestine of fish (Huang et al., 2015). However, no information is available about the relationship between $\mathrm{YH}$ and TJ structure in fish. Therefore, further research is warranted to deepen our knowledge on the mechanisms of $\mathrm{YH}$ response to barrier function in fish.

In conclusion, replacing fish meal with $3 \% \mathrm{YH}$ increased growth performance, intestinal digestive and brush-border enzymes activity, and improved intestinal villus length without exerting any adverse effects on the intestinal TJ structure of Jian carp.

\section{Acknowledgments}

This study was supported by Initial Scientific Research Fund of Huaiyin Institute of Technology (Grant no.Z301B19576) and China Agriculture Research System (Grant no.CARS-45-14).

\section{References}

AOAC 1995. Agricultural chemicals; Contaminants, drugs. In: Official methods of analysis. Association of Official Analytical Chemists, Arlington, USA, 1298 pp.

Baeverfjord, G. 1996. Development and regression of soybean meal induced enteritis in Atlantic salmon, Salmo salar L. distal intestine: A comparison with the intestines of fasted fish. J. Fish. Dis., 19: 375-387. https://doi.org/10.1046/j. 1365-2761.1996.d01-92.x.

Berge, G. M. and Storebakken, T. 1996. Fish protein hydrolyzate in starter diets for Atlantic salmon (Salmo salar) fry. Aquaculture, 145(1-4): 205-212. https://doi.org/10.1016/ S0044-8486(96)01355-5.

Buts, J.P., De Keiser, N., Kolanowski, J., Sokal, E. and Van Hoof, F. 1993. Maturation of villus and crypt cell functions in rat small intestine. Role of dietary polyamines. Digest. Dis. Sci., 38: 1091-1098. https://doi.org/10.1007/BF01295726.

Carter, C. G. and Hauler, R. C. 2000. Fish meal replacement by plant meals in extruded feeds for Atlantic salmon (Salmo salar L.). Aquaculture, 185(3-4): 299-311. https://doi. org/10.1016/s0044-8486(99)00353-1.

Chen, J. R., Suetsuna, K. and Yamauchi, F. 1995. Isolation and characterization of immunostimulative peptides from soybean. J. Nutr. Biochem., 6: 310-313. https://doi. org/10.1016/0955-2863(95)00022-R.

Cupp-Enyard, C. 2008. Sigma's non-specific protease activity assay-casein as a substrate. Jove-J Vis. Exp., 19: 899-900. https://doi.org/10.3791/899.

Cuvier-Peres, A. and Kestemont, P. 2001. Development of some digestive enzymes in Eurasian perch larvae Perca fluviatilis. Fish Physiol. Biochem., 24: 279-285. https://doi. org/10.1023/A:1015033300526.

Decking, U. K., Alves, C., Wallimann, T., Wyss, M. and Schrader, J. 2001. Functional aspects of creatine kinase isoenzymes in endothelial cells. Am. J. Physiol-cell Ph., 281: C320-C328. https://doi.org/10.1152/ajpcell.2001. 281.1.C320.

Dimitroglou, A., Merrifield, D. L., Spring, P., Sweetman, J., Moate, R. and Davies, S. J. 2010. Effects of mannan oligosaccharide (MOS) supplementation on growth performance, feed utilisation, intestinal histology and gut microbiota of gilthead sea bream (Sparus aurata). Aquaculture, 300(1-4): 182-188. https://doi.org/10.1016/j. aquaculture.2010.01.015.

Dufour, C., Dandrifosse, G., Forget, P., Vermesse, F., Romain, N. and Lepoint, P. 1988. Spermine and spermidine induce intestinal maturation in the rat. Gastroenterology, 95: 112-116. http://doi.org/10.1016/0016-5085(88)90298-3.

Ehsani, J., Azarm, H. M., Maniat, M., Ghabtani, A. and Eskandarnia, H. 2014. Effects of partial substitution of dietary fish meal by fermented soybean meal on growth performance, body composition and activity of digestive enzymes of juvenile yellowfin sea bream 
(Acanthopagrus latus). Int. J. Biol. Sci., 5: 99-107. https:// doi.org/10.1016/10.12692/ijb/5.4.99-107.

Engstad, R. E., Robertsen, B. and Frivold, E. 1992. Yeast glucan induces increase in lysozyme and complement-mediated haemolytic activity in Atlantic salmon blood. Fish Shellfish Immunol., 2: 287-297. https://doi.org/10.1016/S10504648(06)80033-1.

Fanning, A. S., Jameson, B. J., Jesaitis, L. A. and Anderson, J. M. 1998. The tight junction protein ZO-1 establishes a link between the transmembrane protein occludin and the actin cytoskeleton. J. Biol. Chem., 273(45): 29745-29753. https://doi.org/10.1074/jbc.273.45.29745.

FAO 2018. FAO yearbook of fishery statistics 2018. Fisheries and Aquaculture Department, Food and Agricultural Organisation of the United Nations, Rome, Italy. http:// www.fao.org/fishery/statistics/global-production/zh.

Furne, M., Hidalgo, M. C., Lopez, A., García-Gallego, M., Morales, A. E., Domezain, A., Domezaine, J. and Sanz, A. 2005. Digestive enzyme activities in Adriatic sturgeon Acipenser naccarii and rainbow trout Oncorhynchus mykiss. A comparative study. Aquaculture, 250: 391-398. https://doi.org/10.1016/j.aquaculture.2005.05.017.

Gause, B. and Trushenski, J. 2011. Replacement of fish meal with ethanol yeast in the diets of sunshine bass (Morone chrysops $\times$ M. saxatilis). N. Am. J. Aquac., 73(2): 97-103. https://doi.org/10.1080/15222055.2011.544939.

Gjellesvik, D., Lombardo, D. and Walther, B. 1992. Pancreatic bilesalt dependent lipase from cod (Gadus morhua): purification and properties. $B B A, 1124: 123-134$. https:// doi.org/10.1016/0005-2760(92)90088-D.

Groschwitz, K. R. and Hogan, S. P. 2009. Intestinal barrier function: Molecular regulation and disease pathogenesis. J. Allergy Clin. Immun., 124:3-20. https://doi.org/10.1016/j. jaci.2009.05.038.

Gui, D., Liu, W., Shao, X. and Xu, W. 2010. Effects of different dietary levels of cottonseed meal protein hydrolysate on growth, digestibility, body composition and serum biochemical indices in crucian carp (Carassius auratus gibelio). Anim. Feed Sci. Tech., 156: 112-120. https://doi. org/10.1016/j.anifeedsci.2010.01.012.

Harpaz, S., Hakim, Y., Barki, A., Karplus, I., Slosman, T. and Tufan, E. O. 2005. Effects of different feeding levels during day and/or night on growth and brush-border enzyme activity in juvenile Lates calcarifer reared in freshwater recirculating tanks. Aquaculture, 248: 325-335. https://doi. org/10.1016/j.aquaculture.2005.04.033.

He, S., Zhou, Z., Meng, K., Zhao, H., Yao, B., Ringø, E. and Yoon, I. 2011. Effects of dietary antibiotic growth promoter and Saccharomyces cerevisiae fermentation product on production, intestinal bacterial community, and non-specific immunity of hybrid tilapia (Oreochromis niloticus female $\times$ Oreochromis aureus male). J. Anim. Sci., 89(1): 84-92. https://doi.org/10.2527/jas.2010-3032.
Hossain, Z. and Hirata, T. 2008. Molecular mechanism of intestinal permeability: Interaction at tight junctions. Mol. Bio. Syst., 4(12): 1181-1185. https://doi.org/10.1039/ B800402A.

Hu, L., Yun, B., Xue, M., Wang, J., Wu, X., Zheng, Y. and Han, F. 2013. Effects of fish meal quality and fish meal substitution by animal protein blend on growth performance, flesh quality and liver histology of Japanese seabass (Lateo labrax japonicus). Aquaculture, 372-375: 52-61. https:// doi.org/10.1016/j.aquaculture.2012.10.025.

Huang, Y. W., Ye, Y. T., Cai, C. F., Wu, P., Chen, K. Q., Wu, T., Xu, D. H., Peng, K., Lin, X. X. and Luo, Q. G. 2015. The study on damage of intestinal mucosa barrier structure with oxidized fish oil diets in Ctenopharyngodon idella. J. Fish. China, 39(10): 1511-1520. https://doi.org/10.1299/ kikaia.79.1620.

Jiang, J., Yin, L., Li, J. Y., Li, Q., Shi, D., Feng, L., Liu, Y., Jiang, W. D., Wu, P., Zhao, Y. and Zhou, X. Q. 2017. Glutamate attenuates lipopolysaccharide-induced oxidative damage and mRNA expression changes of tight junction and defensin proteins, inflammatory and apoptosis response signaling molecules in the intestine of fish. Fish Shellfish Immunol., 70: 473-484. https://doi.org/10.1016/j.fsi.2017. 09.035 .

Kafilzadeh, R., Mousavi, S. M. and Baboli, M. J. 2013. Effects of Saccharomyces cerevisiae (Saccharomycetes: Saccharomycetaceae) on Astronotus ocellatus as growth promoter and immunostimulant. AaclBioflux, 6(6): 587-598.

Krogdahl, A., Bakke-McKellep, A. M. and Baeverfjord, G. 2003. Effects of graded levels of standard soybean meal on intestinal structure, mucosal enzyme activities and pancreatic response in Atlantic salmon (Salmo salar L.). Aquac. Nutr., 9: 361-371. https://doi.org/10.1046/j.13652095.2003.00264.x.

Lanari, D., Poli, B. M., Ballestrazzi, R., Lupi, P., Agaro, E. D. and Mecatti, M. 1999. The effects of dietary fat and NFE levels on growing European sea bass (Dicentrarchus labrax L.). Growth rate, body and fillet composition, carcass traits and nutrient retention efficiency. Aquaculture, 79: 351-364. https://doi.org/10.1016/S0044-8486(99)00170-2.

McCormick, S. D. 1993. Methods for nonlethal gill biopsy and measurement of $\mathrm{Na}^{+}, \mathrm{K}^{+}$-ATPase activity. Can. J. Fish Aquat. Sci., 50: 656-658. https://doi.org/10.1139/f93-075.

Mohanta, K. N., Subramanian, S. and Korikanthimath, V. S. 2012. Evaluation of different animal protein sources in formulating the diets for blue gourami, Trichogastertric hopterus fingerlings. J. Aquac. Res. Dev., 4(2): 2-7. https:// doi.org/10.4172/2155-9546.1000164.

Moure, A., Domi'nguez, H. and Parajo, J. C. 2006. Antioxidant properties of ultrafiltration-recovered soy protein fractions from industrial effluents and their hydrolysates. Process Biochem., 41: 447-456. https://doi.org/10.1016/j. procbio.2005.07.014. 
Oliva-Teles, A. and Goncalves, P. 2001. Partial replacement of fishmeal by brewer's yeast (Saccaromyces cerevisae) in diets for seabass (Dicentrarchus labrax) juveniles. Aquaculture, 202(3-4): 269-278. https://doi.org/10.1016/ S0044-8486(01)00777- 3.

Ogawa, M., Shiozawa, M., Hiraoka, Y., Takeuchi, Y. and Aiso, S. 1998. Immunohistochemical study of localization of $\gamma$-glutamyltranspeptidase in the rat brain. Tissue Cell, 30: 597-601. https://doi.org/10.1016/S0040-8166(98)80078-5.

Peñaramos, E. A. and Xiong, Y. L. 2001. Antioxidative activity of whey protein hydrolysates in a liposomal system. J. Dairy Sci., 84: 2577-2583. https://doi.org/10.3168/jds. S0022-0302(01)74711-X.

Pongpet, J., Ponchunchoovong, S. and Payooha, K. 2016. Partial replacement of fishmeal by brewer's yeast (Saccharomyces cerevisiae) in the diets of Thai panga (Pangasianodon hypophthalmus $\times$ Pangasius bocourti). Aquac. Nutr., 22: 575-585. https://doi.org/10.1111/anu.12280.

Roa, O., Bgs, T., Môro, G. V., Lst, O., Portz, L. and Jep, C. 2010. Growth, nitrogen gain and indispensable amino acid retention of pacu (Piaractus mesopotamicus, Holmberg 1887) fed different brewer's yeast (Saccharomyces cerevisiae) levels. Aquac. Nutr., 16(3): 276-283. https:// doi.org/10.1111/j.1365-2095.2009.00662.x.

Rosalki, S. B., Rau, D., Lehmann, D. and Prentice, M. 1970. Gamma-glutamyltranspeptidase in chronic alcoholism. The Lancet, 296(7683): 1139-1139. https://doi.org/10.1016/ S0140-6736(70)92341-X.

Ran, C., Huang, L., Liu, Z., Xu, L., Yang, Y., Tacon, P., Auclair, E. and Zhou, Z. G. 2015. A comparison of the beneficial effects of live and heat-inactivated baker's yeast on Nile tilapia: Suggestions on the role and function of the secretory metabolites released from the yeast. PLoS One, 10: 1-16. https://doi.org/10.1371/journal.pone.0145448.

Sang, H. M., Ky, L. T. and Fotedar, R. 2009. Dietary supplementation of mannan oligosaccharide improves the immune responses and survival of marron, Cherax tenuimanus (Smith, 1912) when challenged with different stressors. Fish Shellfish Immunol., 27(2): 341-348. https:// doi.org/10.1016/j.fsi.2009.06.003.

Tovar, D., Zambonino, J., Cahu, C., Gatesoupe, F. J., VázquezJuarez, R. and Lesel, R. 2002. Effect of live yeast incorporation in compound diet on digestive enzyme activity in sea bass (Dicentrarchus labrax) larvae. Aquaculture, 204(1-2): 113-123. https://doi.org/10.1016/ s0044-8486(01)00650-0.

Weng, C. F., Chiang, C. C., Gong, H. Y., Chen, M. H., Lin, C. J., Huang, W. T., Cheng, C. Y., Hwang, P. P. and Wu, J. L. 2002. Acute changes in gill $\mathrm{Na}^{+}, \mathrm{K}^{+}$-ATPase and creatine kinase in response to salinity changes in the euryhaline teleost, tilapia (Oreochromis mossambicus). Physiol. Biochem. Zool., 75: 29-36. https://doi.org/10.1086/338283.

Wu, Y., Liu, W. B., Li, H. Y., Xu, W. N., He, J. X., Li, X. F. and Jiang, G. Z. 2013. Effects of dietary supplementation of fructooligosaccharide on growth performance, body composition, intestinal enzymes activities and histology of blunt snout bream (Megalobrama amblycephala) fingerlings. Aquac. Nutr., 19: 886-894. https://doi.org/ 10.1111/anu.12033.

Xu, C., Li, X. F., Tian, H. Y., Jiang, G. Z. and Liu, W. B. 2016. Feeding rates affect growth, intestinal digestive and absorptive capabilities and endocrine functions of juvenile blunt snout bream Megalobrama amblycephala. Fish Physiol. Biochem., 42: 689-700. https://doi.org/10.1007/ s10695-015-0169-z.

Yamauchi, F. and Suetsuna, K. 1993. Immunological effects of dietary peptide derived from soybean protein. J. Nutr. Biochem., 4: 450-457. https://doi.org/10.1016/0955-2863 (93)90062-2.

Yan, L. and Zhou, Q. X. 2006. Dietary glutamine supplementation improves structure and function of intestine of juvenile Jian carp (Cyprinus carpio var. jian). Aquaculture, 256(1-4): 389-394. https://doi.org/10.1016/j. aquaculture.2006.02.011.

Yuan, X. Y., Liu, W. B., Liang, C., Sun, C. X., Xue, Y. F., Wan, Z. D. and Jiang, G. Z. 2017. Effects of partial replacement of fish meal by yeast hydrolysate on complement system and stress resistance in juvenile Jian carp (Cyprinus carpio var. jian). Fish Shellfish Immunol., 67: 312-321. https://doi. org/10.1016/j.fsi.2017.06.028.

Zhao, B., Feng, L., Liu, Y., Kuang, S. Y., Tang, L., Jiang, J., Hu, K., Jiang, W. D., Li, S. H. and Zhou, X. Q. 2012. Effects of dietary histidine levels on growth performance, body composition and intestinal enzymes activities of juvenile Jian carp (Cyprinus carpio var jian). Aquac. Nutr., 18: 220-232. https://doi.org/10.1111/j.1365-2095.2011.00898.x. 